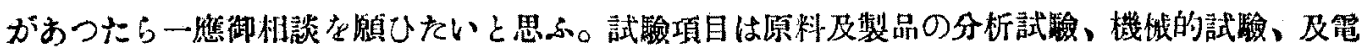

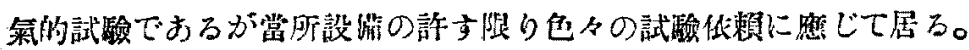

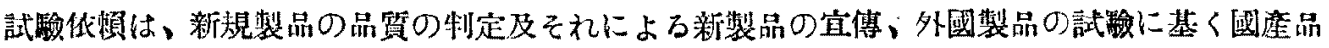

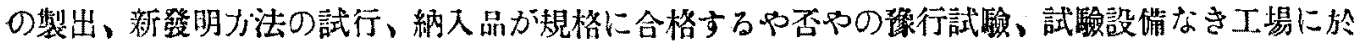

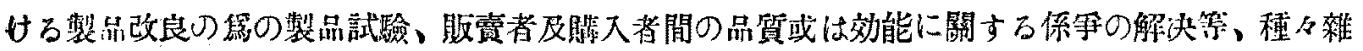

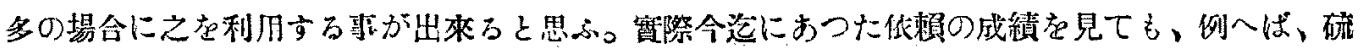

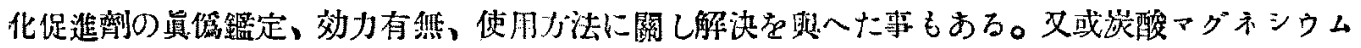

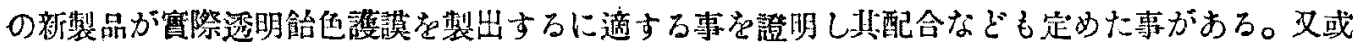

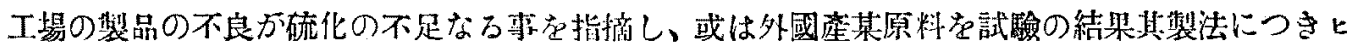
ント発其人得た事もある。

當試驗所第五部の謢謨試俳工場は大震罗數华前より設儌し一㭙燒失したが復舊したもので、恐

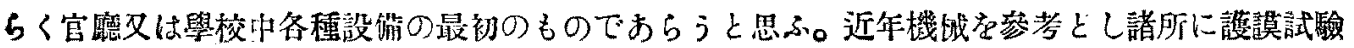

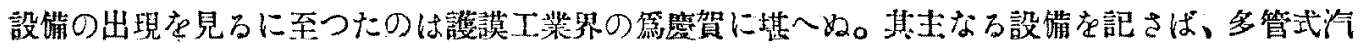

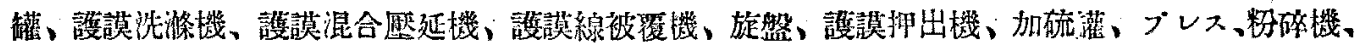

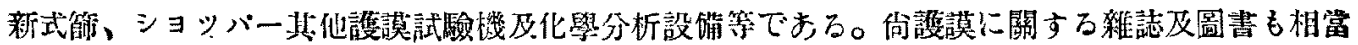
惜へてあるから文献等につき調查御肴望の力は遠虑なく來て御利川おらん事を希望する。

\title{
護謨工業に於ける電氣的測定の應用
}

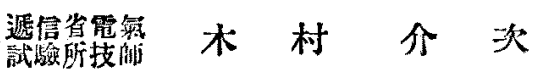

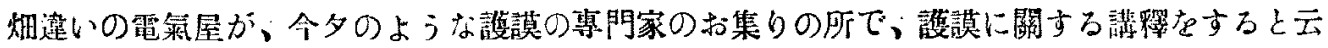
ふことは、甚げ潛越千萬でありますが、幹事のオから是非何かやれ、といふ御命令であるので、

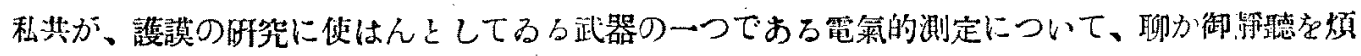
杣し、御批制を願ひ度いと存じます。

元來、私共が護謨に關する时究を行つて居りますのは絕緣物としての謢謨の性質を决定してゆ き度い、と云ふにおるのであるが、寺ひ電氣試驗所にば湊谷氏が居られて十年承護謨の砢究に從

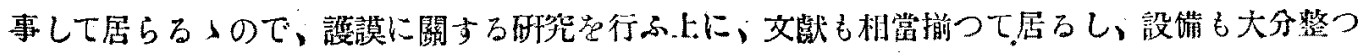

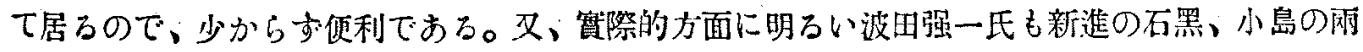

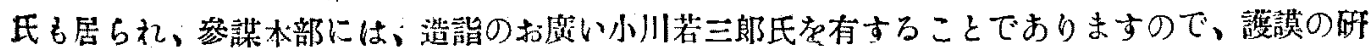




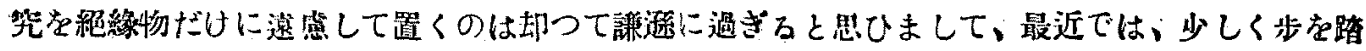
み出してるる次第であります。

\section{研究の武器としての誘麗体損失（Dielectric Loss）の測定}

談謨及其の混和物は、御承知の通り、電氣の紉緣物であります。其の絕緣物の沚質の內で、誘 電体損失なる一つの物理的性質は、護謨混和物の內容を检棠するのによい武器であることに骕が 付きまして、昨年から、之が活朋に力篮して居るのでおります。

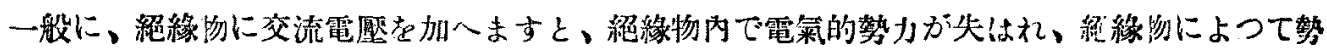

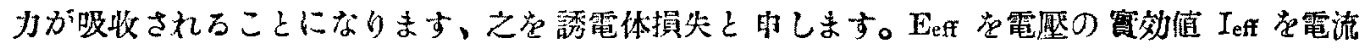
の赛効值としますと、誘電体損失 W は

$$
W=\text { Eeff. }_{\text {eff }} \cos \varphi
$$

で表はされます。即ち誘電体損失は $\cos \varphi$ に比例する、此の $\cos \varphi$ を力率と云ひます。

之を分り易い篇に心゙クトル圖で書きますと；圖のようになりますので、(1)式は、結局、電流

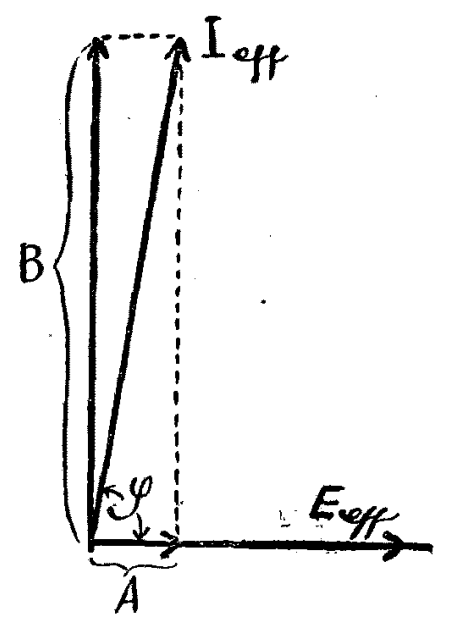

$\mathrm{I}_{\mathrm{eff}}$ の內で、電厴 $\mathrm{E}_{\mathrm{eff}}$ と同じ力向に分けられた分けまへだけ の電流 A と E Eff との積であら、よ云ふことになります。

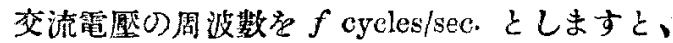

$$
\omega=2 \pi f
$$

を私其は circular frequency と申して居りますが、圖に於け ろ A. Bなる犆は

$$
\begin{aligned}
& \mathbf{A}=\mathrm{G} . \text { Eeff. } . \\
& \mathbf{B}=\omega \mathrm{C} . \mathrm{E}_{\text {eff. }}
\end{aligned}
$$

なる形で表はされます。とと云ふ触は通常 $90^{\circ} に$ に極めて近い 角ですから

$$
\mathrm{B} \simeq \mathrm{I}_{\text {eff. }}
$$

と考えても大差ないのであります。從つて

$$
\cos \varphi=\frac{\mathrm{G}}{\omega \mathrm{C}}
$$

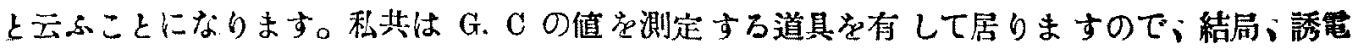
体損夫に比例する力率 $\cos \varphi$ を決定しうることになるのでおります。

営 $\mathrm{C}$ の値から誘電率 $\xi$ を計算することが出來る。

又測定周波數を一定にしますを

$$
\frac{\mathrm{G}}{\mathrm{C}}=\omega \times \cos \varphi
$$


も訜電体損失に比例することになりますから、通常は G/C の值を取つて居ります。

此の $\mathrm{G} / \mathrm{C}$ の值が温度によつて如何に栗すかかと中しますと、畐の宽線で示した曲線のように なるのであります、そして、测定電膯の周波數疮 $f_{1} f_{2} f_{3} f_{4}$ の如く增してゆきますと、此の曲線 は次第に温度の高い力へ移動します。

又誘電卒 $\xi$ の值は $\mathrm{G} / \mathrm{C}$ の値が山描 く處で急激に增加するのでおります。 此の山が何度位の温度に最大點を有 すろか、其の時の最大の $\mathrm{G} / \mathrm{C}$ の値 が如何になるか、と云ふことは、硫化 の程度；及護謨混和物中に於け万種々 の混和娈の存在等に關係があるので、

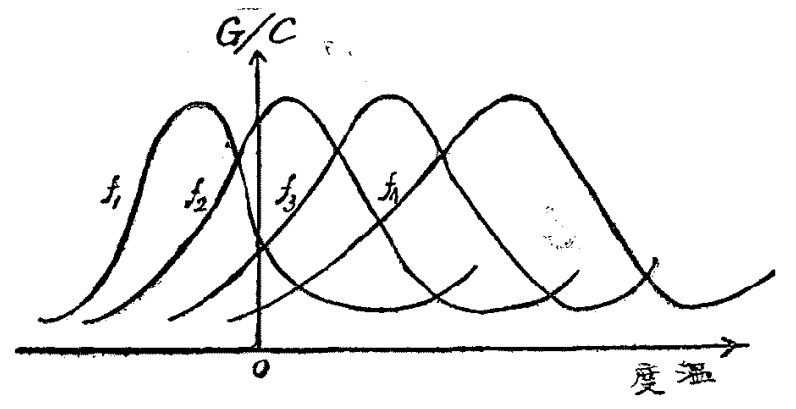
此の $\mathrm{G} / \mathrm{C}$ と温度との關係を温度で知ることによつて、護謨混和物の冈谷が分るのですります。

尤も今夕お話申上るのは、此の武器艮使つて、こんな結論を得たと云ふことを括するのでな くて；此の武器を使つてこんな風な結諭も得られそうであると云ふ、要するに、此の武器の效能 に關する御紹介に過ぎないこと足々も申上て置きます。

\section{硫黄量と力率}

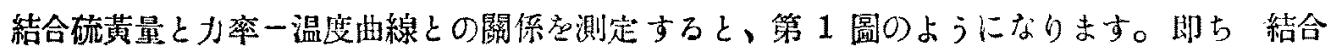
硫黄量が增加すれば山の最大點の温度は，上显し、最大の $\mathrm{G} / \mathrm{C}$ の值も增加することが分る。

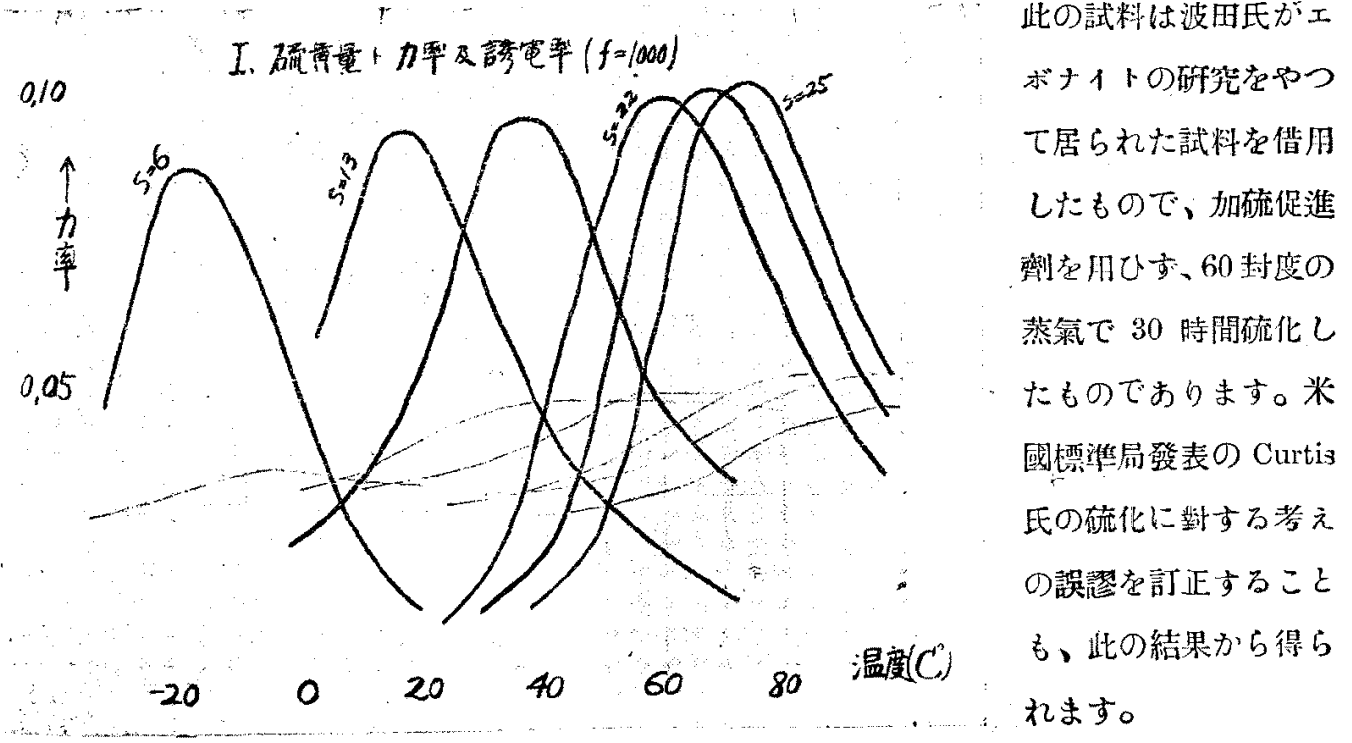

〔電氣學會猍誌昭和 3 年 12 月號; 及日本護謨協會猚誌昭和 3 年 12 月號參照] 
Smoked Sheet 100 に對し、硫畟莪 5 を入れたものを、40籿度の蒸氣で硫化し、硫化時間を じた結果は第 2 圆の如きものでする。即ち 硫化時間と洪に $\mathrm{G} / \mathrm{C}$ の最太點の温度は片し、

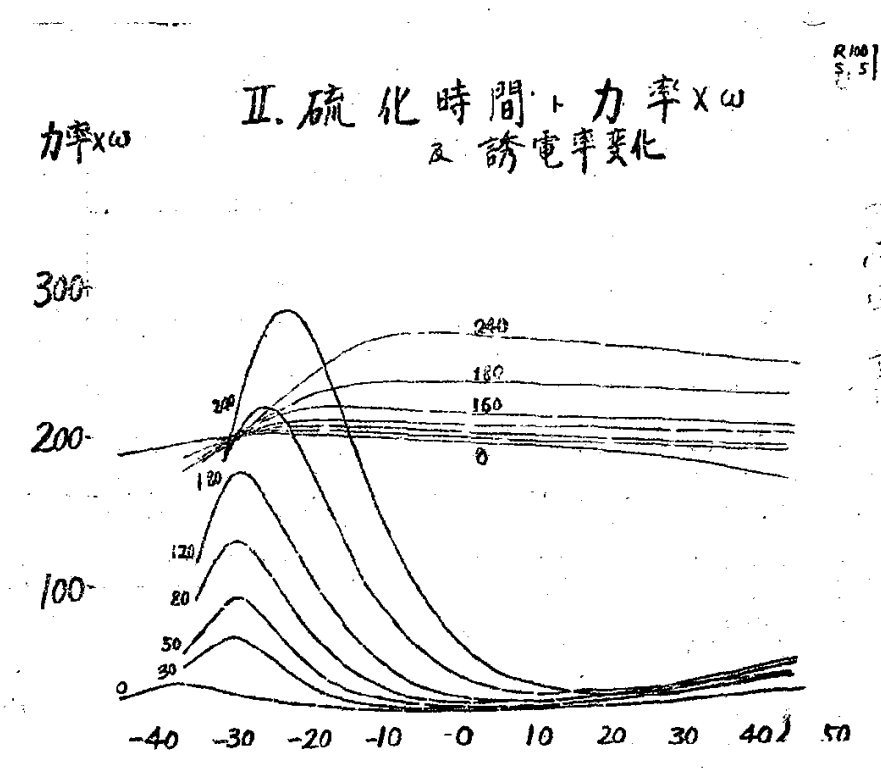

G/C の最大值が增加す

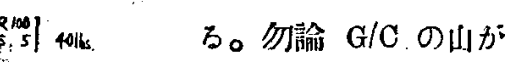
高くなる程川の下に於

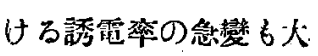
12 に心ります。第 2 圆 の曲線群穵 $-23^{\circ} \mathrm{C}$ 及 1. $\quad-10^{\circ} \mathrm{C}$ の處で切つた 10. 見万と第 3 圖学得ます a 從つ $\tau$ G/C の值觉測 ることによつて、硫化 の充、不充分友知らこ とが出夷万筈でありま す。放 $-23^{\circ} \mathrm{C} \sim-10^{\circ} \mathrm{C}$

で硫化するようなこと

はないから、そんなこ とをしても䁈用に:に應 用出來ないではない か、と云心御質問が出 るかも知れないか、幸 ひにして、測定周波數 を大ならしめ、今はラ ヂオ等で使つて居る短 波長の程度にすると G/C の山の出万温度は大 非常に高い處人持米与 III $G / C+$ 硫化晆間 $G / C$

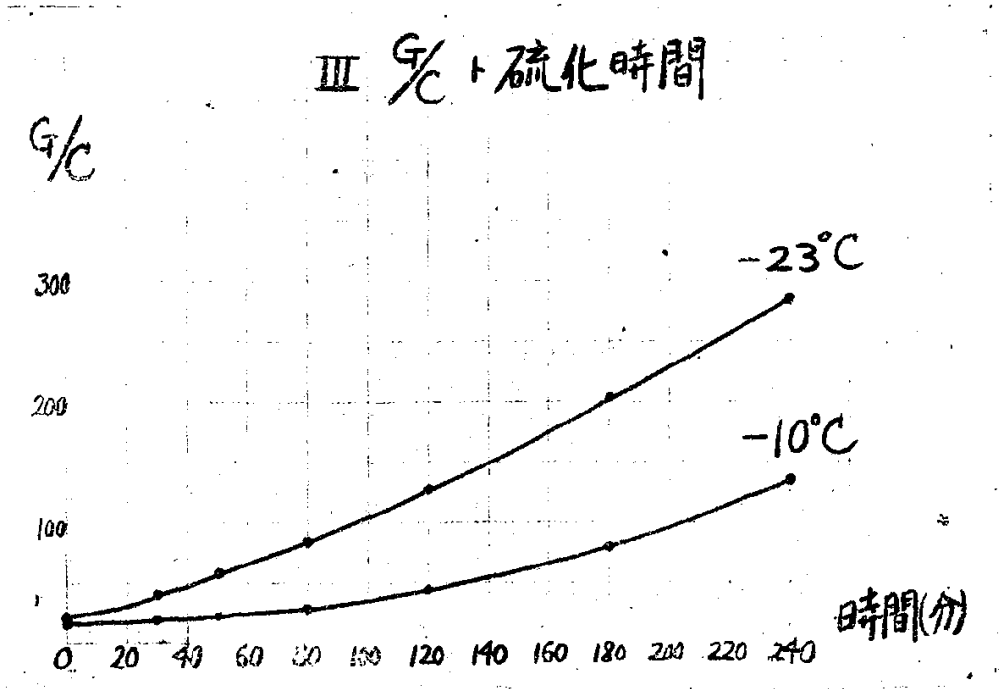

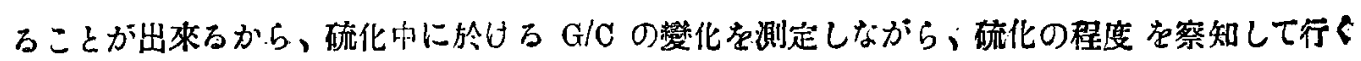
事が出來らと思ふのであります。 


\section{G/C一温度曲線の種々なる應用}

硫黃量を繁じ、硫化時閒と $\mathrm{G} / \mathrm{C}$-温度曲 線を求めた結果； G/C の最大默 $\sigma$ 温长之時 間との關係は第 4 圖のようになりました。 此の試料には MgO ね促進劑として護謨 100 に對し常に 5 だけ入れたのですが、曲線か らして、硫黃 5 を入れなものは 60 分值の 硫化時間 で大部分の硫黃が結合し、硫黄を 10 入れたものに對しては 80 分位で大部分 の硫黃が結合したこと、及び硫橫 3 以下の ものに雃しては $\mathrm{MgO}$ が多きに過ぐることが 分ります。邓之等の曲線によつて硫化速度の 呼笕が可能な゙と思ひます。

硫化現象の理論の方では、最低硫黄量と云

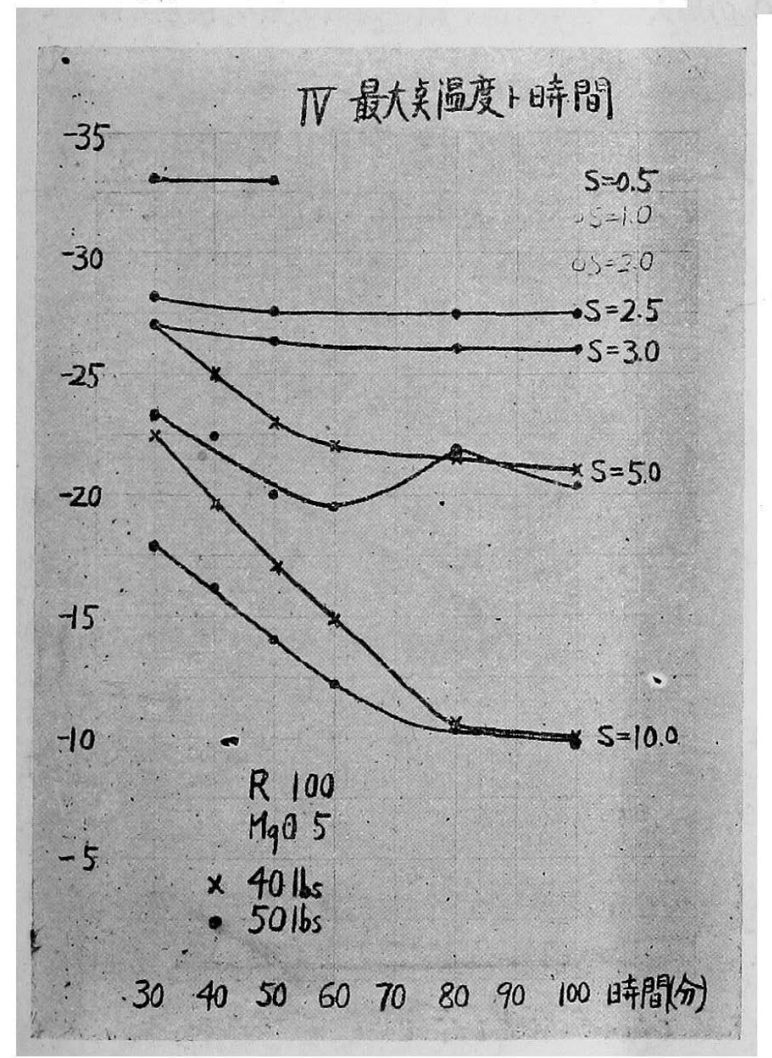

\section{V. 最大 $G / C+$ 硫化時間}

- Mg0.5

$R 100$

$\times 40165$

- $50 \mathrm{lbs}$

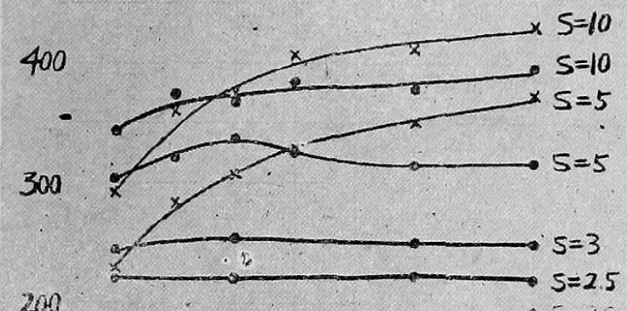

200 , $3=20$

100 $S=0.5$

- $5=0$

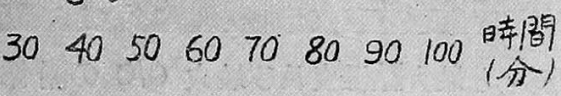

ふことを能く云ひます、即ち、結合硫黄が 護謨 100 に劃して 2.353 以ににならなけ れば、硫化の現象を現はさない、と云は礼 て居りますが、G/C の山の移動から溚へ ますこ、硫橫 0,5 から、硫带 10 位まで の閒、連結的に山の移動があつて；何處に 硫化現象の不連縜默があるかは分りませ ん。從つて、此の結果から見ますと、硫化 に必要な最低硫黃量と云ふものは無いと考 へた方がよいと思はれます。

硫化する時の蒸氣壓を 40lks. と $50 \mathrm{lbs}$. の二つにしてみましたが、50lbs.ので硫化 した結果に於ては第 4 圖第 5 圖共に硫化 㞍りを考えさせるような現象がみられまし た。尤これだけの筫驗ですから確賽なこと は到底分りませんが; 兔も角；硫化が或程 
度進むと不安定な狀態になることが分ります。一般の帣へカとしては、此の不安定になるのす熱 によら護謨の depolymerization に結び付けて居るや；ですが第 6 圖の促進劑を入れない試呌

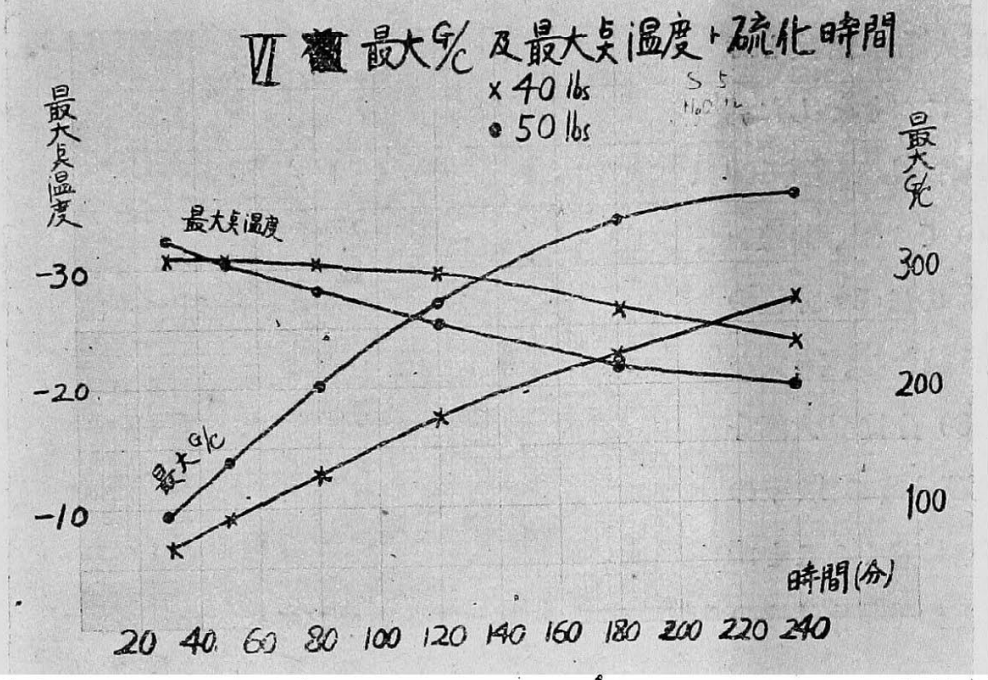
の結果から觀察します と、護謨自身の熱による depolymerization が原因 であるのでなく、何等か 硫化の進行程度に關する ように思はれます。

少第 4 圖及第 5 圖の 100 分目の最大默温度 及び G/C の最大值は、 殆ど混和した硫黃の大部 分が結合し丁つた時の値 だ、と云ふ假定の下に、

硫黄量と最大點温度及び最大 $\mathrm{G} / \mathrm{C}$ の關係を求めてみますと、第 7 圆のようになります。えに よつて G/C-温度曲線の最大點溫度及 $\mathrm{G} / \mathrm{C}$ の最大值を知れば、結合硫黃の量が決定し得るで せう。但し此のお゙は護謨硫黄だけを原料と し、促進劑として $\mathrm{NgO}$ を用ひた時のも のでおつて、基本配合の相違によつて、此 の曲線に變化があるかもしれるぜん。

又热機混和物を入れた場合の $\mathrm{G} / \mathrm{C}$-温 度曲線の一例を擧けをすと、第 8 圖のよ うになります。混和物を入れない試料であ れしば、最大點温度の位置は矢で示した處に あろべきであります。然ろに大部分のもの は，山の位置が温度の高い力へ 2 3 度移 動してるます。それははさもあるべき事柄な のであります。其理由は；元來此の場合の 誘電 体賣失の原因は；今の理諭的見地か ら云ひますと、硫黄が護謨分子に結合し た結果；陰陽 兩極を有する一種の Dipole

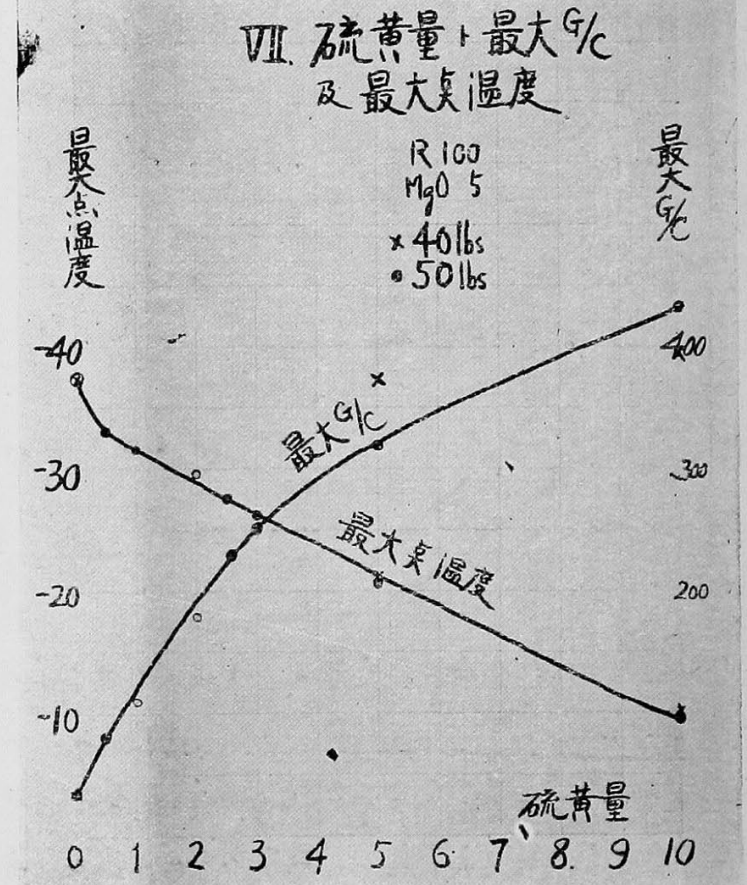
molecule を作り、此の Dipole molecuळ か 
交番電界で迴轉をする覅めに消費されたる勎力損失に起因すると兴えるのであります。從つて混 和物の存在が之等の Dipole molecule の首振り運動を阻むようなものであれば、温度が比晅交的 高くなつて i.nner molecular viscosity が小さくならなければ、混和物の無かつた封と同一の狀 態になりませんから、山の 最大默の位置が;温度の高 い方へ移ろであらうと云ふ

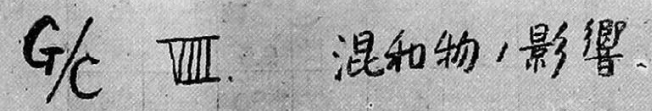

ことは當然学えられる事㑂 であります。比第 8 圖の 曲線の內で一つの山の高さ も低く;最大點の温度も低 い試料がおりますが、之は 亞鉛華に混和したものであ りまして、結果は、亞鉛武 が硫带を喰つた、と云ふこ とを物語つてるます。

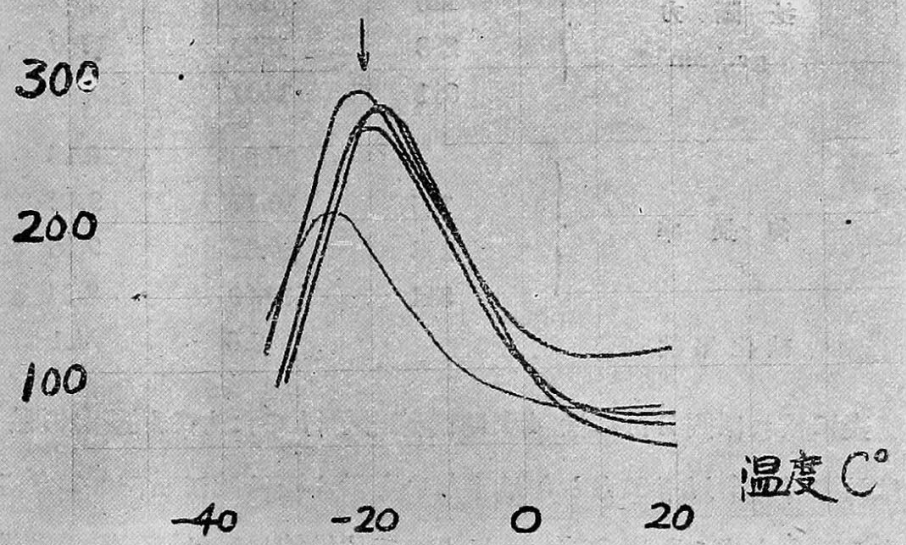

斯樣にして、電氣的測定が; 今後讙謨の険を知る上に、働くべき舞臺は可なり庴いであらう と存じます。若し皆さんが御研焭中のことで、電氣的に测定して見たいと思はれるようなものが おれば裳んで測定して差トげます。（文責低記者小島）

\section{護謨配合劑としてのセレニウムの効果}

昭和 4 年 5 月 14 日铛演

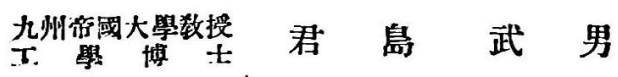

讙謨製品の䝼入に際しその製品に要求する性質はその品により、用途により各々晎ろが一般的 心要求は力强い永持ちするものでおろことは大體一致した要求であらふ。護謨製品の强度は扯斷 力として昔から嚴格に規定され、護謨性狀試驗の重要な一因子であつた。而して扯斷力の强いも のは夫以外の性貿も良い傾向を持つので性質の重な標隼とされて居たのである。かくて長い間こ れを行つて來たが、實を云ふと護謨の性狀試驓としては扯斷的賴り過ぎたのである。その永持 